\title{
PENERAPAN SISTEM PENDUKUNG KEPUTUSAN PEMILIHAN HEWAN PELIHARAAN DENGAN MENGGUNAKAN METODE SIMPLE ADDITIVE WEIGHTING
}

\author{
Manorang Gultom ${ }^{1 *}$ \\ ${ }^{1}$ Sistem Informasi STMIK Widya Dharma Pontianak, Jalan HOS Cokroaminoto Nomor 45 \\ Pontianak Kalimantan Barat Indonesia \\ *manoranggtm@yahoo.com
}

Received: 12 September 2019 Accepted: 1 Desember 2019 Published: 31 Desember 2019

\begin{abstract}
Abstrak
Tujuan penelitian ini adalah untuk menerapkan system pendukung keputusan dalam memberikan rekomendasi kepada seseorang untuk menentukan pilihan hewan yang akan dipelihara. Dalam penelitian ini ditentukan sebanyak 5 (lima) alternatif hewan peliharaan yaitu Burung Beo Nias, Anjing Buldog, Kucing Persia, Kelinci Rex dan Iguana Hijau. Teknik pengumpulan data dilakukan dengan cara membuat quisioner kepada mahasiswa untuk mendapatkan nilai bobot dari setiap alternatif berdasarkan 5 (lima) kriteria, yaitu Kesetiaan, Ketenaran, Penampilan, Harga dan Kandang. Selanjutnya data dianalisis secara kuantitatif dengan menggunakan metode Simple Additive Weighting. Hasil analisis akan memberikan sebuah prioritas pilihan diantara alternatif yang ada. Berdasarkan hasil analisis alternatif yang ada dengan menggunakan metode Simple Additive Weighting, maka didapatkan rekomendasi atau prioritas pilhan pertama adalah Anjing Bulldog dan pilihan kedua adalah Burung Beo Nias.
\end{abstract}

Kata kunci: sistem pendukung keputusan, simple additive weighting, pets.

\section{Abstract}

The purpose of this research is to implement a decision support system in providing recommendations to a person to determine the choice of animals to be preserved. In this study was determined as many as 5 (five) alternative pets are Nias parrot, Buldog dog, Persian cat, Rabbit Rex and Green Iguana. Data collection techniques are done by making Quisioner to the student to get the weight value of each alternative based on 5 (five) criteria, namely loyalty, fame, appearance, price and cage. Furthermore, data is analyzed quantitatively by using Simple Additive Weighting method. The results of the analysis will provide a priority choice among existing alternatives. Based on the results of an alternative analysis using Simple Additive Weighting method, the recommendation or priority of the first choice is the Bulldog dog and the second option is the Nias parrot.

Keywords: decision support system, simple additive weighting, pets

(C) 2019 LPPM IKIP PGRI Pontianak, Indonesia

\section{PENDAHULUAN}

Hobi atau kegemaran adalah sesuatu hal yang biasa dimiliki oleh setiap manusia. Setiap manusia memiliki hobi atau kegemaran yang berbeda beda, salah satu contoh hobi adalah memelihara hewan. Ada saatnya manusia memiliki hobi yang harus memilih diantara alternatif pilihan yang ada, misalnya seseorang memiliki hobi untuk memelihara hewan, maka dia akan 
membuat pilihan hewan apa yang akan dipelihara sehingga tujuan memelihara hewan tersebut yaitu mendapatkan hiburan dan kesenangan dapat dinikmati semaksimal mungkin. Seseorang memiliki hobi biasanya dimanfaatkan untuk mendapatkan hiburan dan kesenangan. Jika salah memilih alternatif, maka hiburan dan kesenangan yang diharapkan tidak akan dapat dirasakan.

Terdapat berbagai jenis hewan yang lajim dipelihara oleh manusia sebagai hiburan atau kesenagan, diantaranya Kucing, Anjing, Marmut, Burung, kelinci dan lain sebagainya. Banyak pertimbangan yang harus dipikirkan oleh calon pemelihara hewan agar tujuan memelihara hewan tersebut yaitu hiburan dan kesenangan dapat tercapai selama memelihara hewan yang dipilih. Pertimbangan yang harius dipikirkan misalnya adalah tempat hewan yang harus disediakan, kesetiaan hewan, penampilan, harga dan lain sebagainya. Berdasarkan uraian diatas, permasalahan yang ada adalah bagaimana memilih hewan peliharaan yang baik sehingga tujuan pemeliharaan hewan dapat dicapai. Permasalahan ini akan diatasi melalui tahapan analisis data dengan menggunakan metode Simple Additive Weighting.

Hewan peliharaan adalah hewan yang dipelihara oleh manusia yang harus dirawat dan dipenuhi kebutuhan hidupnya serta memiliki tempat yang layak. Hewan peliharaan dapat dianggap sebagai teman bagi manusia. Hewan peliharaan pada umumnya adalah hewan yang memiliki karakter setia pada pemiliknya, memiliki penampilan yang menarik, memiliki suara yang indah, betingkah lucu atau menggemaskan, unik dan dapat menghibur pemiliknya. Hewan peliharaan yang menjadi objek dalam penelitian ini adalah Burung Beo Nias, Anjing Buldog, Kucing Persia, Kelinci Rex dan Iguana Hijau.

Syatama (2019) mengungkapkan bahwa Burung Beo Nias adalah hewan yang banyak diminati pencinta hewan untuk dipelihara. Keunikan yang dimiliki oleh burung ini menjadi daya tarik bagi pecinta burung Beo Nias. Banyak orang yang suka menjadikan burung Beo Nias ini sebagai peliharaan untuk menghibur diri karena kemampuannya untuk meniru vokal manusia.

Admin (2017) mengungkapkan bahwa Anjing Bulldog Inggris (English Bulldog) sangat populer di Indonesia karena jenis anjing ini memiliki tubuh berotot, penampilannya bagus, dan sifatnya sangat lembut. Selain itu, Anjing Bulldog Prancis (French Bulldog), varian English Bulldog, lebih kecil, lebih lembut, dan jenis ini juga telah dicintai oleh banyak orang. Harga anjing Bulldog (English dan French) sangat tinggi.

Haryunta (2019) mengungkapkan bahwa Kucing untuk jenis persia adalah kucing berbulu panjang, wajah yang bulat dan mulut yang pendek menjadi daya tarik bagi para peminat kucing. Kucing jenis ini dinamakan persia karena kucing ini endemik di wilayah Persia dimana sekarang dikenal dengan negara Iran. Pada awal abad ke 19, kucing dengan jenis persia ini dikembangkan di negara Inggris. 
Noname (2019) mengungkapkan bahwa Kelinci adalah salah satu jenis hewan yang banyak dipelihara oleh para pencinta hewan, dimana hewan dengan jenis rex ini banyak ditemukan di wilayah Prancis. Kelinci ini memiliki ciri-ciri yang berbeda dari jenis kelinci lainnya, seperti kepala yang lebih besar serta telinga yang lebar dan tegak. Berwarna mayoritas hitam, putih, biru, tricolor hingga kombinasi warna, membuat kelinci ini begitu populer di Eropa. Kini di Indonesia kelinci rex mulai memiliki peminat yang lumayan dikarenakan memiliki karakteristik yang berbeda.

Noname (2018) mengungkapkan bahwa Ciri fisik yang umum dari iguana ini adalah pada bagian bawah rahangnya terdapat lipatan kulit, memiliki sisik besar bundar yang cukup besar pada pipinya yang disebut dengan selubung subtimpani. Keunikan dari iguana adalah hewan ini memiliki penglihatan yang bagus sehingga dapat melihat bayangan, melihat warna serta untuk membidik mangsanya dari kejauhan. Selain itu mata pada iguana juga digunakan untuk berkomunikasi dengan sesama spesies. Iguana memiliki sebuah telinga yang disebut timpanium jika diperhatikan letak dari tipanum atau merupakan gendang telinga ini berada bagian kanan atas selubung subtimpani dan ada juga yang terletak pada bagian belakang mata. Iguana hijau adalah salah satu jenis hewan peliharaan yang cukup simpel. Tetapi bagi yang belum pernah memelihara iguana, pasti akan kebingungan. Dengan penanganan yang tepat iguana akan jinak tidak mudah stres. Jika salah penanganan iguana malah bisa galak. Jika ingin memelihara iguana, disarankan memilih iguana yang masih kecil. Ukuran anak iguana yang berumur kurang dari 1 tahun memiliki panjang dari kepala sampai pangkal ekor 20-30 cm dengan berat 1-1,5 kg.

Algoritma Simple Additive Weighting adalah sebuah algoritma yang banyak digunakan oleh para peneliti untuk membuat sistem pengambilan keputusan. Algoritma ini dikenal juga sebagai algoritma dengan konsep kerja penjumlahan berbobot. Algoritma Simple Additive Weighting ini melakukan normalisasi matrix keputusan x ke dalam skala yang dapat di perbandingkan dengan rating alternatif yang lain.

Menurut Nofriansyah, Dicky \& Defit (2017) Algoritma Simple Additive Weighting dapat difahami sebagai algoritma dengan pembobotan sederhana atau dengan kata lain algoritma ini melakukan penjumlahan terbobot pada penyelesaian masalah dalam sebuah sistem pendukung keputusan yang akan dibuat. Tahapan penyelesaian dari algoritma ini adalah Mendefinisikan kriteria yang akan di buat sebagai tolok ukur penyelesaian permasalahan, Melakukan normalisasi dari setiap nilai alternatif atribut yang ada dengan cara mengkalkulasi nilai rating kinerja, Mengkalkulasi nilai bobot preferensi dari setiap alternative dan Menentukan rangking dari setiap alternatif.

Menurut Febrina (2018) Algoritma Simple Additive Weighting adalah suatu algoritma yang sering digunakan untuk menentukan alternatif optimal dari sejumlah alternatif yang ada dengan kriteria tertentu. Rumus untuk melaksanakan normalisasi dapat dilihat pada Persamaan 1. 


$$
r_{i j}=\left\{\begin{array}{l}
\frac{x_{i j}}{\operatorname{Max}_{i} x_{i j}} \text { Jika } j \text { adalah atribut keuntungan (benefit) } \\
\frac{\operatorname{Min} x_{i j}}{x_{i j}} \text { Jika } j \text { adalah atribut biaya }(\text { cost) }
\end{array}\right.
$$

Dimana $r_{i j}$ adalah rating kinerja ternormalisasi, xij baris atau kolom dari matrik, $\operatorname{Max}_{\mathrm{i}} \mathrm{x}_{\mathrm{ij}}$ adalah nilai maksimum dari baris dan kolom serta $\operatorname{Min}_{\mathrm{i}} \mathrm{X}_{\mathrm{ij}}$ adalah nilai minimum dari baris dan kolom.

Nilai preferensi untuk tiap alternative $\left(\mathrm{V}_{\mathrm{i}}\right)$ ditentukan dengan Persamaan 2.

$$
V_{i}=\sum_{j=1}^{n} W_{j} r_{i j}
$$

Dengan $\mathrm{V}_{\mathrm{i}}$ adalah nilai akhir dari setiap alternative, $\mathrm{w}_{\mathrm{j}}$ adalah bobot yang ditentukan dan $\mathrm{r}_{\mathrm{ij}}$ adalah hasil normalisasi matriks. Nilai $\mathrm{V}_{\mathrm{i}}$ yang lebih besar mengindikasikan bahwa alternatif $\mathrm{A}_{\mathrm{i}}$ lebih dominan untuk dipilih.

Menurut Nofiansyah dan Defit (2017) “Algoritma dengan metode Simple Additive Weighting dapat di fahami sebagai suatu algoritma dengan konsep kerja dimana algoritma ini akan melakukan pembobotan atau penjumlahan terbobot pada setiap penyelesain masalah dari sebuah sistem pendukung keputusan.

Menurut Sari (2018) Algoritma Simple Additive Weighting adalah suatu algoritma yang banyak digunakan untuk menentukan alternatif yang paling optimal dari beberapa alternatif yang ada dengan kriteria yang telah ditentukan. Algoritma Simple Additive Weighting ini akan menentukan nilai bobot dari setiap atribut yang kemudian dilanjutkan dengan perangkingan yang akan memilih alternatif yang sudah diberikan. Tahapan penentuan keputusan dari Algoritma Simple Additive Weighting adalah Menentukan alternatif pilihan, Menentukan kriteria dari setiap alternatif yang menjadi acuan saat penentuan keputusan, Memberikan nilai rating kecocokan dari setiap alternatif pada setiap kriteria yang ada, Menentukan bobot preferensi setiap kriteria, Membuat tabel rating kesesuaian dari setiap alternatif pada setiap kriteria yang ada, Membuat matriks keputusan x yang dibuat berdasarkan tabel rating kesesuaian dari setiap alternatif pada semua kriteria, Melaksanakan normalisasi matrik keputusan $\mathrm{x}$ dengan menghitung nilai rating kinerja ternormalisasi dari setiap alternatif Ai pada setiap kriteria $\mathrm{Cj}$, dimana akan dilakukan pengkategorian, apakah $\mathrm{j}$ merupakan kriteria keuntungan (benefit) atau biaya (cost). Disebut kriteria benefit atau keuntungan apabila nilai xij memberikan keuntungan bagi pengambil keputusan, sebaliknya dikatakan kriteria biaya atau cost apabila xij menimbulkan biaya bagi pengambil keputusan. Jika kriteria merupakan keuntungan atau benefit, maka nilai xij dibagi dengan nilai Max,i(xij) dari setiap kolom, sedangkan jika kriteria merupakan biaya atau cost, maka nilai Min,i(xij) dari setiap kolom dibagi dengan nilai xij. Hasil nilai rating kinerja ternormalisai $\left(\mathrm{r}_{\mathrm{ij}}\right)$ akan membentuk matrik ternormalisasi. Selanjutnya Hasil perhitungan akhir nilai preferansi diperoleh dari penjumlahan setiap perkalian elemen baris matrik 
ternormalisasi dengan bobot preferensi yang bersesuaian dengan elemen kolom matrik. Menentukan Nilai indikasi. Penentuan rangking dilakukan dengan cara melakukan perkalian nilai $\mathrm{W}$ dengan nilai Indikasi. Hasil perkalian akan di rangking sesuai urutan nilai paling besar sampai yang terkecil.

Menurut pendapat Mulyani (2016) Sistem Pendukung Keputusan atau Decision Support System adalah sebuah sistem yang membantu seorang pimpinan untuk memecahkan sebuah permasalahan dalam penentuan pilihan dari berbagai alternatif yang tersedia. Menurut Nofiansyah dan Defit (2017) Sebuah Sistem Pendukung Keputusan adalah suatu sistem informasi yang ditujukan untuk membantu para pihak manajemen suatu organisasi dalam menentukan keputusan. Menurut Muslihudin dan Oktafianto (2016) Sistem Pendukung Keputusan atau Decision Support System adalah merupakan suatu sistem informasi pada tingkat pimpinan dari suatu organisasi yang menghubungkan data dan model analisis atau peralatan data analisis untuk mendukung pengambilan keputusan.

Sistem pendukung keputusan dengan metode Simple Additive Weightng yang digunakan dalam penelitian ini bertujuan untuk membantu para calon pemelihara hewan untuk menentukan hewan peliharaan sehingga diharapkan hasil pilihan merupakan pilihan yang terbaik, sehingga kepuasan dalam memelihara hewan dapat dirasakan secara optimal.

\section{METODE}

Penelitian ini dilaksanakan secara deskriptif kuantitatif. Objek penelitian ini adalah hewan peliharaan sebanyak lima alternative dengan lima kriteria. Sumber data sekunder yang akan dianalisis diperoleh dari hasil quisioner yang disebar ke mahasiswa. Teknik analisis data dilakukan dengan menggunakan algoritma Simple Additive Weighting dengan tahapan proses kerja yang terdiri dari beberapa tahap disajikan pada Gambar 1.

Tahap terakhir merupakan hasil akhir dari analisis data yang menghasilkan suatu nilai dari setiap alternative yang ada berdasarkan kriteria yang sudah ditentukan. Secara terurut nilai maksimal merupakan rekomendasi pemilihan dari lima alternative yang dapat dipilih oleh calon pemelihara hewan. 


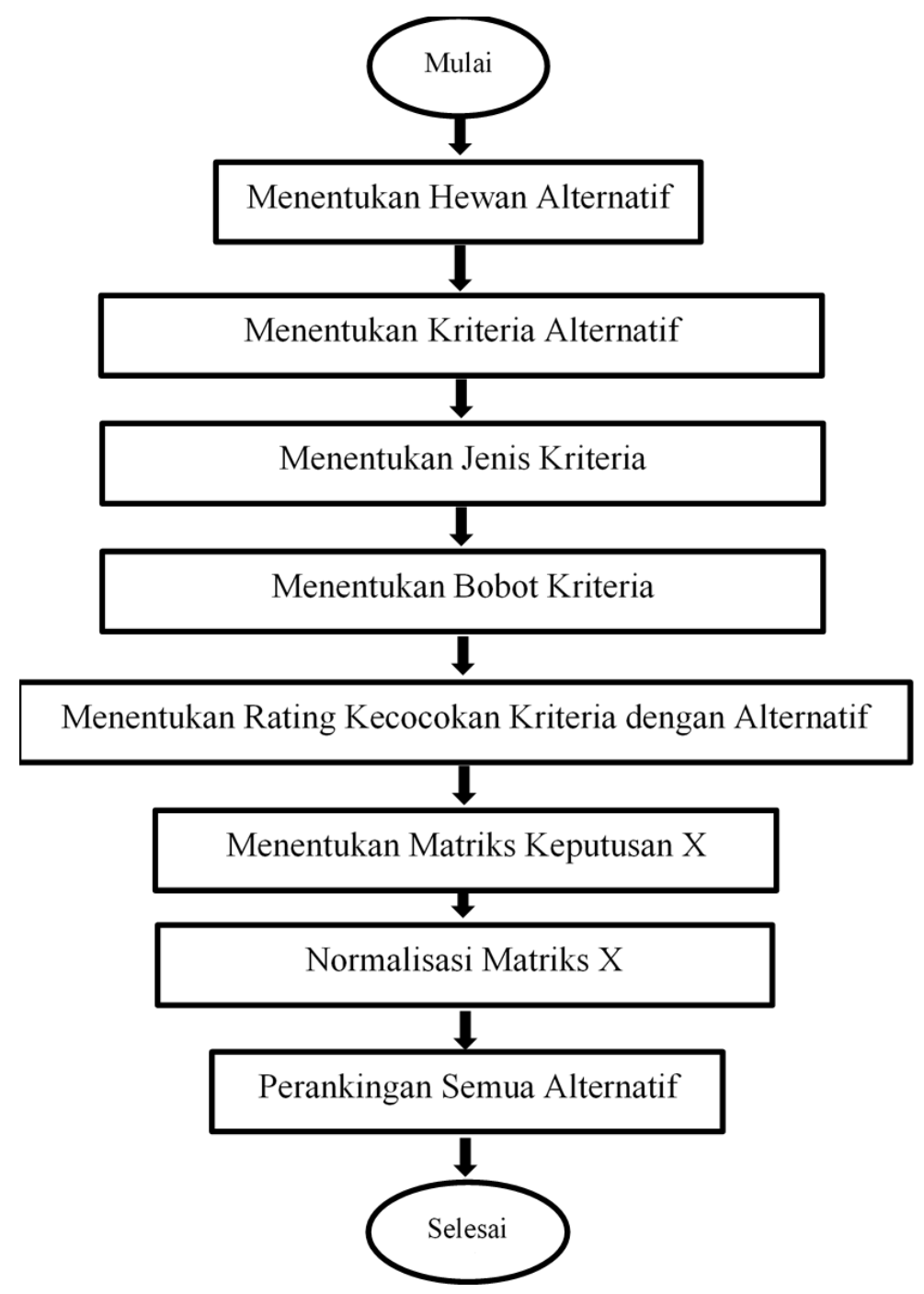

Gambar 1. Tahapan proses kerja algoritma simple additive weighting

\section{HASIL DAN PEMBAHASAN}

Sistem pendukung keputusan digunakan sebagai alat bantu rekomendasi dan memperluas kapabilitas para pengambil keputusan untuk menentukan keputusan. Metode Simple Additive Weighting dalam Sistem Pendukung Keputusan diharapkan dapat memberikan rekomendasi alternatif-alternatif pilihan hewan peliharaan yang akan dipilih untuk dipelihara. Konsep dasar metode SAW adalah mencari penjumlahan terbobot dari rating hasil perhitungan pada setiap alternatif untuk semua kriteria yang ditentukan. Metode SAW membutuhkan proses normalisasi matrik keputusan (X) ke suatu skala yang dapat diperbandingkan dengan semua alternatif yang ada, sebelumnya dibutuhkan syarat sebagai berikut: 


\section{Menentukan Alternatif (Kandidat)}

Alternatif yang dimaksud di sini merupakan kandidat hewan peliharaan pada penelitian ini yang nantinya akan disebut $\mathrm{A}_{\mathrm{i}}$ dimulai dari $\mathrm{A}_{1}, \mathrm{~A}_{2} \ldots \mathrm{A}_{\mathrm{n}}$. Daftar hewan peliharaan yang digunakan sebagai sampel disajikan pada Tabel 1.

Tabel 1. Alternatif hewan peliharaan

\begin{tabular}{cc}
\hline Alternatif & Nama Hewan \\
\hline A1 & Burung Beo Nias \\
A2 & Anjing Buldog English \\
A3 & Kucing Persia \\
A4 & Kelinci Rex \\
A5 & Iguana Hijau \\
\hline
\end{tabular}

\section{Menentukan Kriteria}

Kriteria ditandai dengan $C_{i}$ dimulai $C_{1}, C_{2}, \ldots C_{n}$. Kriteria pada SAW merupakan bagian yang digunakan sebagai acuan dalam pengambilan keputusan. Kriteria tersebut dikelompokkan menjadi dua jenis yaitu kriteria benefit yang berarti memberikan keuntungan bagi pengambil keputusan dan kriteria cost yang berarti membutuhkan biaya bagi pengambil keputusan. Kriteria yang akan digunakan dalam penelitian ini disajikan pada Tabel 2.

Tabel 2. Kriteria

\begin{tabular}{llc}
\hline Kode Kriteria & Nama Kriteria & Jenis Kriteria \\
\hline C1 & Kesetiaan & Benefit \\
C2 & Ketenaran & Benefit \\
C3 & Warna & Benefit \\
C4 & Harga & Cost \\
C5 & Kandang & Cost \\
\hline
\end{tabular}

\section{Nilai Rating Tiap Alternatif Untuk Setiap Kriteria}

Pemberian nilai rating terhadap setiap alternatif untuk setiap kriteria diperlukan dalam perhitungn SAW. Agar mengetahui nilai rating tersebut dibutuhkan nilai prepeferensi untuk setiap keriteria yaitu kesetiaan, keternaran, warna/penampilan, harga dan kandang.

Kesetiaan hewan peliharaan merupakan faktor yang paling penting yang menjadi pertimbangan saat memilih hewan peliharaan. Hewan peliharaan yang tidak setia akan mengakibatkan tujuan kesenangan atau hiburan saat memelihara hewan tidak akan tercapai. Dengan demikian 
pertimbangan memilih hewan peliharaan yang dianggap paling setia sangat menentukan kepuasan selama memelihara hewan tersebut. Kriteria kesetiaan dan bobot yang telah ditentukan untuk setiap alternatif disajikan pada Tabel 3.

Tabel 3. Kriteria kesetiaan

\begin{tabular}{ccc}
\hline Kode Kriteria & Kesetiaan & Nilai \\
\hline KS1 & Sangat Tidak Setia & 0,1 \\
KS2 & Tidak Setia & 0,4 \\
KS3 & Setia & 0,7 \\
KS4 & Sangat Setia & 1 \\
\hline
\end{tabular}

Ketenaran hewan merupakan nilai tambah bagi hewan yang akan dipelihara. Terkadang pemelihara hewan peliharaan mengabaikan harga demi mendapatkan hewan peliharaan yang sangat tenar khususnya bagi komunitas pemelihara hewan. Ketenaran hewan peliharaan dapat disebabkan oleh beberapa hal, yaitu suara yang bagus, warna bulu yang menarik dan tingkat kesetiaan. Kriteria ketenaran dari hewan peliharaan disajikan pada Tabel 4.

Tabel 4. Kriteria ketenaran

\begin{tabular}{clc}
\hline Kode Kriteria & \multicolumn{1}{c}{ Kesetiaan } & Nilai \\
\hline KT1 & Sangat Tidak Tenar & 0,1 \\
KT2 & Tidak Tenar & 0,4 \\
KT3 & Tenar & 0,7 \\
KT4 & Sangat Tenar & 1 \\
\hline
\end{tabular}

Warna hewan merupakan nilai tambah bagi hewan yang akan dipelihara. Terkadang pemelihara hewan peliharaan mengabaikan harga demi mendapatkan hewan peliharaan yang sangat menarik dari segi warna atau penampilan hewan, oleh sebab itu penampilan dan warna hewan merupakan salah satu faktor pertimbangan bagi calon pemelihara hewan Kriteria warna dari hewan peliharaan disajikan pada Tabel 5.

Tabel 5. Kriteria warna/penampilan

\begin{tabular}{clc}
\hline Kode Kriteria & \multicolumn{1}{c}{ Kesetiaan } & Nilai \\
\hline WP1 & Sangat Tidak Menarik & 0,2 \\
WP2 & Tidak Menarik & 0,5 \\
WP3 & Menarik & 0,8 \\
WP4 & Sangat Menarik & 1 \\
\hline
\end{tabular}


Harga merupakan salah satu bagian terpenting dari kebanyakan orang dalam memilih/mempertimbangkan sebuah hewan peliharaan sebab mereka memiliki kebiasaan menentukan anggaran terlebih dahulu. Perbedaan harga yang dimiliki hewan peliharaan tentu dapat membedakan fitur dan keunggulan yang dimiliki sebuah hewan peliharaan. Nilai rating kriteria harga dijabarkan pada Tabel 6.

Tabel 6. Kriteria harga

\begin{tabular}{clc}
\hline Kode Kriteria & Harga & Nilai \\
\hline HG1 & Sangat Mahal & 0,2 \\
HG2 & Mahal & 0,4 \\
HG3 & Tidak Mahal & 0,6 \\
HG4 & Sangat Tidak Mahal & 0,8 \\
\hline
\end{tabular}

Menyediakan kandang untuk hewan peliharaan adalah sesuatu hal yang wajib dilakukan oleh setiap pemelihara hewan. Untuk menyediakan kandang harus disesuaikan dengan hewan yang dipelihara. Biaya untuk penyediaan kandang membutuhkan biaya yang harus disiapkan oleh si pemelihara hewan. Biaya ini juga merupakan pertimbangan yang harus di pikirkan saat memilih hewan peliharaan. Nilai kriteria untuk kandang hewan peliharaan disajikan pada Tabel 7.

Tabel 7. Kriteria kandang

\begin{tabular}{clc}
\hline Kode Kriteria & Kandang & Nilai \\
\hline KN1 & Sangat Luas & 0,2 \\
KN2 & Luas & 0,4 \\
KN3 & Tidak Luas & 0,6 \\
KN4 & Sangat Tidak Luas & 0,8 \\
\hline
\end{tabular}

Berdasarkan hasil quisioner yang disebar sebanyak 35 orang mahasiswa, maka diperoleh nilai rata-rata dari penilaian setiap alternatif dengan masing-masing kriteria seperti pada Tabel 8.

Tabel 8. Rating kecocokan alternatif-kriteria

\begin{tabular}{cccccc}
\hline Alternatif/Kriteria & KS & KT & WP & HG & KN \\
\hline A1 & 1 & 0,7 & 1 & 0,4 & 0,4 \\
A2 & 1 & 1 & 0,8 & 0,2 & 0,6 \\
A3 & 1 & 0,7 & 0,5 & 0,6 & 0,6 \\
A4 & 0,7 & 0,7 & 0,2 & 0,4 & 0,6 \\
A5 & 0,7 & 0,7 & 0,8 & 0,6 & 0,8 \\
\hline
\end{tabular}




\section{Menentukan Nilai Bobot Alternatif Terhadap Kriteria}

Berdasarkan Tabel 8 tentang rating kecocokan alternatif-kriteria diatas, maka dibentuk matriks keputusan X seperti disajikan pada Gambar 2.

$\sum$\begin{tabular}{c|c|c|c|c|c|c|c|}
\hline & 1 & 0,7 & 1 & 0,4 & 0,4 & \\
\hline 1 & 1 & 0,8 & 0,2 & 0,6 & \\
\hline 1 & 0,7 & 0,5 & 0,6 & 0,6 \\
\hline 0,7 & 0,7 & 0,2 & 0,4 & 0,6 & \\
\hline & 0,7 & 0,7 & 0,8 & 0,6 & 0,8 & - \\
\hline
\end{tabular}

\section{Gambar 2. Matrix X}

Pembobotan kriteria dilakukan dengan memberikan nilai tertentu pada masing-masing kriteria secara langsung. Pembobotan kriteria dapat juga dilakukan dengan menggunakan fuzzy logic. Penggunaan Fuzzy logic dianjurkan jika kritieria yang dipilih memiliki sifat yang unik atau relative. Dalam penelitian ini nilai pembobotan masing-masing kriteria di asumsikan secara langsung seperti Tabel 9.

Tabel 9. Pembobotan kriteria

\begin{tabular}{cc}
\hline Kriteria & Bobot \\
\hline C1 & 0,40 \\
C2 & 0,25 \\
C3 & 0,20 \\
C4 & 0,10 \\
C5 & 0,05 \\
Total & 1 \\
\hline
\end{tabular}

\section{Melakukan Normalisasi Matrix X menjadi Matrix R Menggunakan Persamaan 1.}

Kriteria Harga, dan Kandang (C4 dan C5) termasuk atribut biaya (cost), dikarenakan pemelihara hewan harus mengeluarkan sejumlah biaya untuk membeli bahan dan membuat kandang hewan peliharaan, semakin kecil nilai harga dan kandang maka dianggap semakin baik dalam pemilihan hewan peliharaan. Untuk normalisasi nilai harga dan kandang digunakan Persamaan 3.

$$
\mathrm{R}_{\mathrm{ii}}=\left(\min \left\{\mathrm{X}_{\mathrm{ij}}\right\} / \mathrm{X}_{\mathrm{ij}}\right)
$$

Berdasarkan kolom C3 nilai minimum adalah '0,2', maka semua baris dari kolom C3 menjadi penyebut dari nilai maksimum kolom C3, sehingga didapat hasil dari Persamaan 3 sebagai berikut: 


$$
\begin{aligned}
& \mathrm{R} 13=0,2 / 0,4=0,5 \\
& \mathrm{R} 23=0,2 / 0,2=1,0 \\
& \mathrm{R} 33=0,2 / 0,6=0,3 \\
& \mathrm{R} 43=0,2 / 0,4=0,5 \\
& \mathrm{R} 53=0,2 / 0,4=0,5
\end{aligned}
$$

Kriteria kesetiaan, Warna/Penampilan dan Ketenaran termasuk atribut keuntungan (benefit), dikarenakan calon pemelihara hewan akan memiliki rasa kebanggaan memiliki hewan tersebut, semakin besar nilainya maka dianggap semakin baik dalam pemilihan hewan peliharaan. Untuk normalisai nilai Kesetiaan dan ketenaran digunakanan Persamaan 4.

$$
\mathrm{R}_{\mathrm{ii}}=\left(\mathrm{X}_{\mathrm{ij}} / \max \left\{\mathrm{X}_{\mathrm{ij}}\right\}\right)
$$

Berdasarkan kolom C1 nilai maksimum adalah '1', maka semua baris dari kolom C1 dibagi oleh nilai maksimum kolom C1 sehingga didapat hasil dari Persamaan 4.

$\begin{array}{lll}\mathrm{R} 11 & =1 / 1= & 1,0 \\ \mathrm{R} 21 & =1 / 1= & 1,0 \\ \mathrm{R} 31 & =1 / 1= & 1,0 \\ \mathrm{R} 41 & =0,7 / 1= & 0,7 \\ \mathrm{R} 51 & =0,7 / 1= & 0,7\end{array}$

Berdasarkan kolom C2 nilai maksimaum adalah '1', maka tiap baris dari kolom C2 menjadi penyebut dari nilai maksimum kolom C2, sehingga didapat hasil dari Persamaan 4.

$\begin{array}{lll}\mathrm{R} 12 & =0,7 / 1= & 0,7 \\ \mathrm{R} 22 & =1 / 1= & 1,0 \\ \mathrm{R} 32 & =0,7 / 1= & 0,7 \\ \mathrm{R} 42 & =0,7 / 1= & 0,7 \\ \mathrm{R} 52 & =0,7 / 1= & 0,7\end{array}$

Berdasarkan persamaan normalisasi matriks $\mathrm{X}$ maka diperoleh matriks $\mathrm{R}$ yang ternormalisasi seperti Gambar 3.

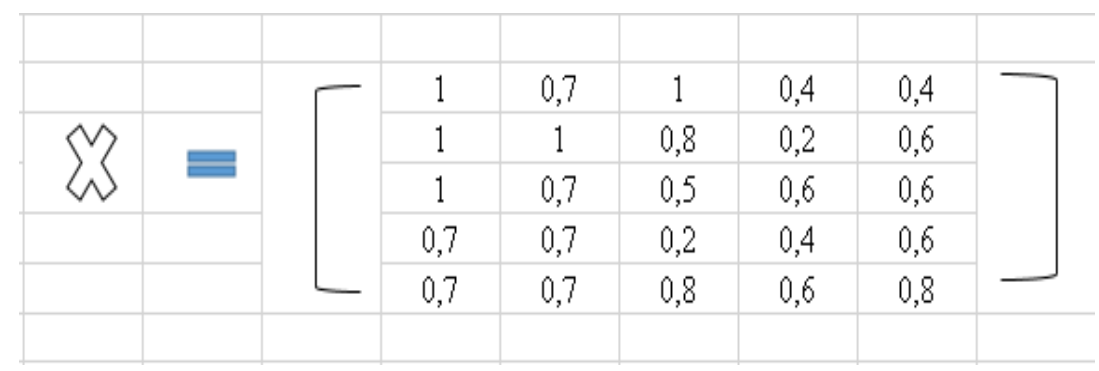

Gambar 3. Matrix X ternormalisasi 


\section{Proses Penentuan Ranking Dilakukan Menggunakan Persamaan 2}

Berdasarkan Persamaan 2, maka diperoleh ranking seperti di bawah ini.

$$
\begin{aligned}
\mathrm{V}_{1} & =(1)(0,4)+(0,7)(0.25)+(1)(0,2)+(0,4)(0,10)+(0,4)(0,05) \\
& =0,4+0,175+0,2+0,04+0,02 \\
& =\mathbf{0 , 8 3 5} \\
\mathrm{V}_{2} & =(1)(0,4)+(1)(0.25)+(0,8)(0,2)+(0,2)(0,10)+(0,6)(0,05) \\
& =0,4+0,25+0,16+0,02+0,03 \\
& =\mathbf{0 , 8 6 0} \\
\mathrm{V}_{3} & =(1)(0,4)+(0,7)(0.25)+(0,5)(0,2)+(0,6)(0,10)+(0,6)(0,05) \\
& =0,4+0,175+0,1+0,06+0,03 \\
& =\mathbf{0 , 7 6 5} \\
\mathrm{V}_{4} & =(0,7)(0,4)+(0,7)(0.25)+(0,2)(0,2)+(0,4(0,10)+(0,6)(0,05) \\
& =0,28+0,175+0,04+0,04+0,03 \\
& =\mathbf{0 , 5 9 5} \\
\mathrm{V}_{5} & =(0,7)(0,4)+(0,7)(0.25)+(0,8)(0,2)+(0,6(0,10)+(0,8)(0,05) \\
& =0,21+0,175+0,16+0.06+0,04 \\
& =\mathbf{0 , 7 4 5}
\end{aligned}
$$

Berdasarkan hasil kalkulasi maka diperoleh, urutan priorotas hewan peliharaan yang disarankan berdasarkan metode Simple Additive Weighting seperti disajikan pada Tabel 10.

Tabel 10. Perankingan urutan prioritas peliharaan

\begin{tabular}{cclc}
\hline No & Kode & Alternatif hewan & Nilai \\
\hline 1 & V2 & Anjing Buldog & 0,860 \\
2 & V1 & Burung Beo Nias & 0,835 \\
3 & V3 & Kucing Persia & 0,765 \\
4 & V5 & Iguana Hijau & 0,745 \\
5 & V4 & Kelinci Rex & 0,595 \\
\hline
\end{tabular}

Berdasarkan Tabel 10, maka hasil penelitian menyarankan untuk memilih hewan peliharaan diantara kelima hewan tersebut alternativ pertama adalah memelihara anjing Bulldog dan sebagai alternative yang kedua adalah burung Beo Nias. Berdasarkan analisis data yang dilakukan oleh peneliti, hasil penelitian ini dipengaruhi oleh penentuan nilai serta bobot kriteria. Dalam penelitian ini penentuan nilai dan bobot kriteria ditentukan sendiri oleh peneliti. Untuk lebih mengoptimalkan hasil penelitian sebaiknya penentuan nilai dan bobot kriteria menggunakan metode yang lebih baik misalnya metode fuzzy. Penerapan Fuzzy Multi Atribute Decision Making (Fuzzy MADM) pada sistem pendukung keputusan yang menggunakan metode Fuzzy SAW (Simple Additive Weighting), 
akan menentukan nilai bobot untuk setiap kriteria yang ditentukan, kemudian dengan proses perangkingan akan menyeleksi alternatif yang terbaik dari sejumlah alternatif yang ada

\section{SIMPULAN}

Berdasarkan hasil penelitian yang dilakukan, maka diperoleh beberapa simpulan bahwa Anjing Buldog dapat dijadikan sebagai prioritas pilihan diantara alterntif hewan peliharaan yang ada karena hewan ini memiliki nilai ranking tertinggi dari alternative lain. Algoritma Simple Additive Weighting dapat dijadikan sebagai suatu cara untuk membuat sistem pendukung keputusan pemilihan hewan peliharaan, sehingga keputusan yang diambil dapat memberikan keuntungan yang optimal kepada para calon pemelihara hewan.

\section{DAFTAR PUSTAKA}

Admin. 2017. Harga anjing bulldog (English dan French). Retrieved from https://hewanpeli.com/jual-beli-harga-anjing-bulldog/.

Deni, W., Sudana, O. \& Sasmita, A. (2013). Analysis and implementation fuzzy multi-attribute decision making saw method for selection of high achieving students in faculty level. IJCSI International Journal of Computer Science, 10(2).

Elistri, M., Wahyudi, J., \& Supardi, R. (2014). Penerapan metode saw dalam sistem pendukung keputusan pemilihan jurusan pada Sekolah Menengah Atas Negeri 8 Seluma. Jurnal Media Infotama, 10(2), 1858-2680.

Haryunta. (2019). Harga kucing persia. Retrieved from https://longgroveonline.com/harga-kucingpersia/.

Iriane \& Rinduh G. (2013). Analisis penggabungan metode saw dan metode topsis untuk mendukung keputusan seleksi penerimaan dosen. Seminar Nasional Informatika 1979-2328.

Kusumadewi, S., Hartati, S., Harjoko, \& Wardoyo R. (2006). Fuzzy multi attribute decision making (Fuzzy MADM). Yogyakarta: Graha Ilmu

Nofriansyah, Dicky \& Defit. (2017). Multi criteria decision making (MCDM) pada sistem pendukung keputusan. Deepublish. Yogyakarta.

Noname. (2018). Mengenal lebih jauh hobby baru pelihara. Retrieved from http://petfoodreport.com/mengenal-lebih-jauh-hobby-baru-pelihara-iguana/.

Noname. (2019). Harga kelinci rex di Indonesia. Retrieved from https://farmbos.com/harga-kelincirex-di-indonesia/\#z.

Pratama, R. P., Werdiningsih, I, \& Puspitasari, I. (2017). Sistem pendukung keputusan pemilihan siswa berprestasi di sekolah menengah pertama dengan metode VIKOR dan TOPSIS. $J$. Inf. Syst. Eng. Bus. Intell, 3(2), 113-121. 
Sari, \& Febrina. (2018). Metode dalam pengambilan keputusan. Deepublish. Yogyakarta.

Syatama. (2019). Harga burung beo. Retrieved from https://hargaburung.id/harga-burung-beo/. 